\title{
Adverse Effects of Using 0.12\% Chlorhexidine Digluconate: A Literature Review
}

ISSN: 2637-7764

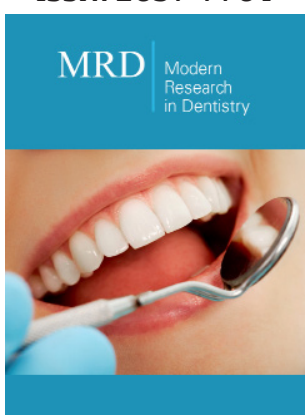

*Corresponding author: Jurandi Nery Pereira, Filho State Universty of Feira de Santana, Feira de Santana, Bahia, Brasil

Submission: 跲 May 05, 2020

Published: 眥June 23, 2020

Volume 5 - Issue 2

How to cite this article: Jurandi Nery Pereira, Thaís Brito Oliveira. Adverse Effects of Using $0.12 \%$ Chlorhexidine Digluconate: A Literature Review. Mod Res Dent. 5(2). MRD.000607. 2020.

DOI: 10.31031/MRD.2020.05.000607

Copyright@ Jurandi Nery Pereira, This article is distributed under the terms of the Creative Commons Attribution 4.0 International License, which permits unrestricted use and redistribution provided that the original author and source are credited.

\author{
Jurandi Nery Pereira* and Thaís Brito Oliveira \\ Filho State Universty of Feira de Santana, Feira de Santana, Bahia, Brasil \\ Federal Universty of Bahia, Salvador, Bahia, Brasil
}

\begin{abstract}
s
As a chemical control, $0.12 \%$ chlorhexidine digluconate is the most widespread in the lineage of mouthwashes. In addition to the effective action of chlorhexidine in dental biofilm, its use is also indicated for oral mucositis, as it acts in reducing the severity of injuries, providing more comfort and avoiding secondary infections. However, the use of chlorhexidine for prolonged periods is contraindicated, as it induces side effects such as discoloration of the teeth, peeling of the mucosa, altered taste and unpleasant taste. In our literature review work, we concluded that $0.12 \%$ chlorhexidine digluconate is an excellent antimicrobial agent, but its use should be done with discretion, as it has significant adverse effects.
\end{abstract}

\section{Introduction}

In times of pandemic, health and hygiene care must be doubled. A healthy body helps the immune system to prevent infections. Therefore, the concern of health authorities regarding the new coronavirus (Sars-Cov-2) is justified. In this sense, attention to oral hygiene is of fundamental importance since the mouth is the gateway for numerous infectious agents. The use of chemical adjuvants is recommended, as it reduces the microbial load to which the organism is subjected. However, the use of such substances can cause some undesired effects, which we will see below in relation to $0.12 \%$ chlorhexidine digluconate, considered the "gold standard" of mouthwashes [1]. As a chemical control, $0.12 \%$ chlorhexidine digluconate is the most widespread in the lineage of mouthwashes [1]. In addition to the effective action of chlorhexidine on dental biofilm, its use is also indicated for oral mucositis, as it acts in reducing the severity of injuries, providing more comfort and avoiding secondary infections [2].

Chlorhexidine has a substantivity in the oral cavity for approximately 12 hours, inhibiting the adhesion and colonization of microorganisms to dental elements. Thus, it can be emphasized that it exerts bactericidal action when used in high concentrations and bacteriostatic in low doses, paralyzing and killing bacteria [1-3]. However, even with numerous beneficial effects, some adverse effects have been observed in the literature regarding its use, such as: alteration in the coloration of dental elements, restorations, prostheses and tongue, formation of supragingival calculus, loss of taste, burns in tissue soft, pain, dry mouth, and unpleasant aftertaste in the mouth. Mucosal ulcerations, reversible swelling of the lips and parotid glands, scaly lesions, urticaria, dyspnea and anaphylactic shock can rarely occur [4-6].

\section{Literature Review}

Chlorhexidine is an antimicrobial and antiseptic agent widely used in the health area, however, it can cause oral changes such as: changes in the color of the dental elements, loss of taste, soft tissue burns, pain, dry mouth, scaly lesions, mucosal ulcerations and unpleasant aftertaste in the mouth [4]. According to Zanatta \& Rösing [4], the change in dental color (Figure 1), which is reported by most users, is strongly associated with its prolonged use, concentration and high volume, affecting mainly the cervical face of the crown and the proximal areas of the dental elements. However, these stains are easily removed with the use of 
ultrasound (Figure 2). these authors also address hypotheses about the factors that lead to staining, such as the ability of chlorhexidine to denature proteins, form ferric and stony sulfite, or even with the association of colored foods, however for Bohner [7] the staining is caused by diet dyes, which react with the mouthwash, forming colored elements. Berton et al. [5] describe the clinical management of unilateral parotid edema caused by the use of chlorhexidine in a 66-year-old patient who used the substance continuously.
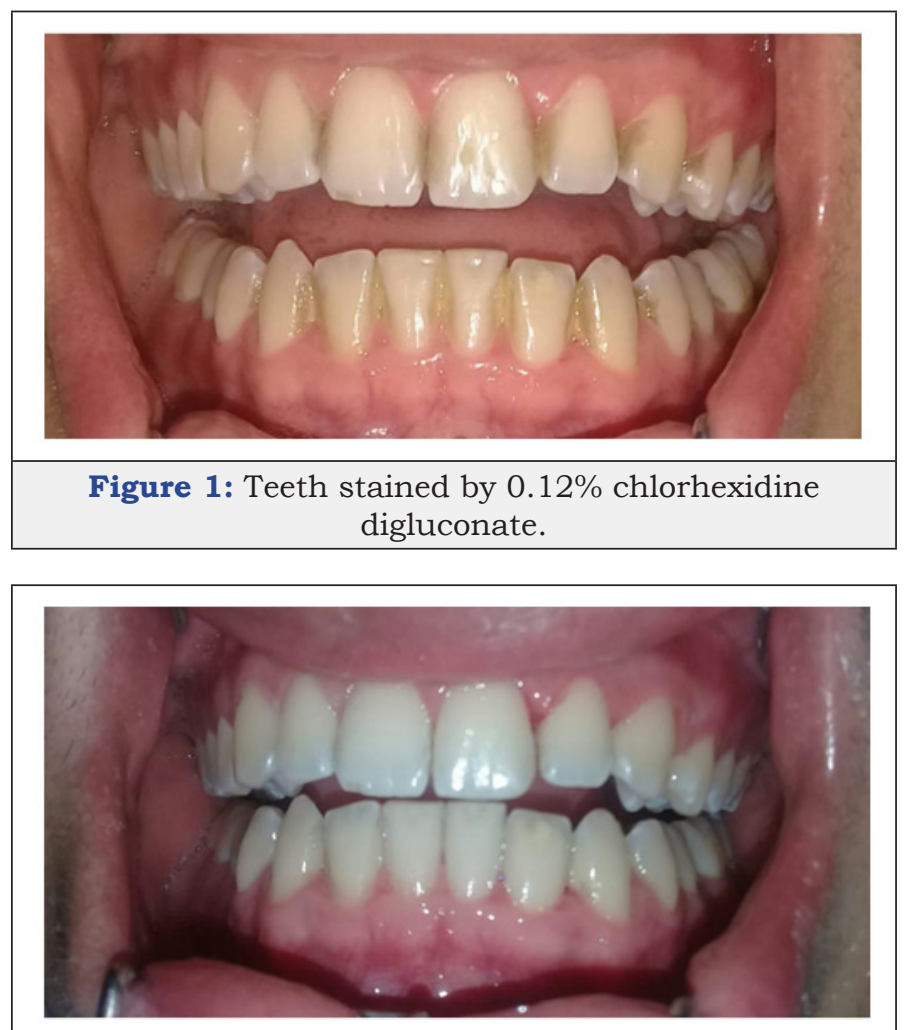

Figure 2: Appearance after ultrasound treatment.

According to Torres et al. [8] it is necessary for the professional to make a correct anamnesis and clinical diagnosis of the patient in order to be more careful when performing invasive procedures in patients with systemic diseases and heart valves, so avoiding compromising the patient's health. It is necessary in the preoperative period to perform extra-oral asepsis and rinse with chlorhexidine, as well as to use it in the postoperative period to prevent the development of infections, always guiding the patient on the form and days of use to avoid effects collaterals in the oral cavity. The most widely used form of chlorhexidine at a concentration of $0.12 \%$ in dentistry is through mouthwash, the amount of which is $15 \mathrm{ml}$, twice a day, rinsing for 60 seconds $[1,2,4]$. In a recent study, Ambhore and Padhye showed the effectiveness of using chlorhexidine in gel form [9]. On the other hand, Campos et al. [10] reported the use of chlorhexidine by the medical team three times a day and mouthwash with $10 \mathrm{ml}$ of $0.12 \%$ chlorhexidine solution for 60 seconds. The use in high doses, acts in the coagulation of cytoplasmic proteins and bacterial death, in low doses, it causes a change in the cell membrane and extravasation of low molecular weight bacteria $[2,4]$.
As emphasized by Franco et al. [11], chlorhexidine acts in two ways, when used in low concentrations, it has bacteriostatic action, paralyzing the bacterium, through the alteration of the osmotic balance and the loss of intracellular substances. Already in high concentrations it has bactericidal action, which ends up destroying the cell. Chlorhexidine is also effective in preventing and treating mucositis in patients undergoing radiotherapy and chemotherapy [8]. These authors emphasize that the MASCC (Multinational Association of Supportive Care in Cancer) and ISOO (International Society of Oral Oncology) do not recommend its use in cancer patients. Ribeiro Junior et al. [12] reported that even though chlorhexidine is used on a large scale in the control of mucositis, it generates oral burning and dysgelsia in addition to reducing mucin levels, affecting the salivary glands by the effects of radiation, leading to xerostomia. Thus, we can conclude that $0.12 \%$ chlorhexidine digluconate is an excellent antimicrobial agent, however its use should be done with discretion, as it has significant adverse effects.

\section{References}

1. Mccoy LC, Wehler CJ, Rich SE, Garcia RI, Miller DR, et al. (2008) Adverse events associated with chlorhexidine use. Results from the department of veterans affairs dental diabetes study. J Am Dent Assoc 139(2): 178183.

2. Gondim FM, Gomes IP, Firmino F (2010) Prevenção e tratamento da mucosite oral. Rev Enferm UERJ 18(1): 67-74.

3. Rudolf JL, Moser C, Sculean A, Eick S (2019) In-vitro antibiofilm activity of chlorhexidine digluconate on polylactide-based and collagen-based membranes. BMC Oral Health 19(1): 291.

4. Zanatta FD, Rösing CKC (2007) Clorexidina: mecanismos de ação e evidências atuais de sua eficácia do contexto do biofilme supragengival. Scientific-A 1(2): 35-43.

5. Berton F, Pipinato G, Maglione M, Baldi D, Di Lenarda R, et al. (2018) Parotid gland edema after chlorhexidine mouthrinse: Case report and literature review. The Open Dentistry Journal 12: 1147-1151.

6. Guimarães ARD, Peres MA, Vieira RS, Ferreira RM, Ramos-Jorde ML, et al. (2006) Self-perception of side effects by adolescents in a chlochexidinefluorede-based preventive oral health program. J Appl Oral Sci 14(4): 291-296.

7. Bohner LOL (2013) Ação do enxaguatório bucal a base de Casearia Sylvestris e Clorexidina $0,12 \%$ na cor e rugosidade superficial do esmalte dental submetido ao clareamento caseiro e bebida alimentícia ácida. Dissertação (Mestrado em Odontologia)-Faculdade de Odontologia de Ribeirão Preto, Universidade de São Paulo, Ribeirão Preto, Brasil.

8. Torres CRG, Kubo CH, Anido AA, Rodrigues JR (2000) Agentes antimicrobianos e seu potencial de uso na Odontologia. Pós-Grad Rev Fac Odontol 3(2): 45-52.

9. Ambhore SR, Padhye AM (2020) Comparative evaluation of the efficacy of Triphala gel and chlorhexidine digluconate gel in management of patients with chronic gingivitis: A randomized clinical trial. J Int Oral Health 12(2): 140-144.

10. Campos CC, Machado GCM, Gonçalves IMF, Amorim LFG, Vieira LAC, et al. (2010) Clínica Odontológica Infantil Passo a Passo. Goiânia Vol 1.

11. Franco APGO, Santos FA, Martins GC, Pilatti G, Gomes OMM, et al. (2007) Desinfecção de cavidades com clorexidina. Ci Biol 13(1/2): 53-58.

12. Ribeiro Junior O, Borba AM, Guimarães Junior J (2010) Prevenção e tratamento da mucosite bucal: o papel fundamental do cirurgiãodentista-Revisão. Rev Clin Pesq Odontol 6(1): 57-62. 
For possible submissions Click below:

\section{Submit Article}

